Biogeosciences, 10, 1083-1095, 2013

www.biogeosciences.net/10/1083/2013/

doi:10.5194/bg-10-1083-2013

(c) Author(s) 2013. CC Attribution 3.0 License.

\title{
Nitrogen balance of a boreal Scots pine forest
}

\author{
J. F. J. Korhonen ${ }^{1}$, M. Pihlatie ${ }^{1}$, J. Pumpanen ${ }^{2}$, H. Aaltonen ${ }^{2}$, P. Hari ${ }^{2}$, J. Levula ${ }^{3}$, A.-J. Kieloaho ${ }^{1}$, E. Nikinmaa ${ }^{2}$, \\ T. Vesala ${ }^{1}$, and H. Ilvesniemi ${ }^{4}$ \\ ${ }^{1}$ Department of Physics, University Of Helsinki, P.O. Box 48, 00014, Helsinki, Finland \\ ${ }^{2}$ Department of Forest Sciences, University Of Helsinki, P.O. Box 27, 00014, Helsinki, Finland \\ ${ }^{3}$ Hyytiälä Forestry Field station, Hyytiäläntie 124, 35500, Korkeakoski, Finland \\ ${ }^{4}$ Finnish Forest Research Institute, Vantaa Unit, P.O. Box 18, 01301, Vantaa, Finland
}

Correspondence to: J. F. J. Korhonen (janne.fj.korhonen@helsinki.fi)

Received: 20 July 2012 - Published in Biogeosciences Discuss.: 20 August 2012

Revised: 11 December 2012 - Accepted: 14 January 2013 - Published: 15 February 2013

\begin{abstract}
The productivity of boreal forests is considered to be limited by low nitrogen $(\mathrm{N})$ availability. Increased atmospheric $\mathrm{N}$ deposition has altered the functioning and $\mathrm{N}$ cycling of these $\mathrm{N}$-sensitive ecosystems by increasing the availability of reactive nitrogen. The most important components of $\mathrm{N}$ pools and fluxes were measured in a boreal Scots pine stand in Hyytiälä, Southern Finland. The measurements at the site allowed direct estimations of nutrient pools in the soil and biomass, inputs from the atmosphere and outputs as drainage flow and gaseous losses from two microcatchments. $\mathrm{N}$ was accumulating in the system, mainly in woody biomass, at a rate of $7 \mathrm{~kg} \mathrm{Nha}^{-1} \mathrm{yr}^{-1}$. Nitrogen input as atmospheric deposition was $7.4 \mathrm{~kg} \mathrm{Nha}^{-1} \mathrm{yr}^{-1}$. Dry deposition and organic $\mathrm{N}$ in wet deposition contributed over half of the inputs in deposition. Total outputs were $0.4 \mathrm{~kg} \mathrm{Nha}^{-1} \mathrm{yr}^{-1}$, the most important outputs being $\mathrm{N}_{2} \mathrm{O}$ emission to the atmosphere and organic $\mathrm{N}$ flux in drainage flow. Nitrogen uptake and retranslocation were equally important sources of $\mathrm{N}$ for plant growth. Most of the assimilated $\mathrm{N}$ originated from decomposition of organic matter, and the fraction of $\mathrm{N}$ that could originate directly from deposition was about $30 \%$. In conclusion, atmospheric $\mathrm{N}$ deposition fertilizes the site considerably, but there are no signs of $\mathrm{N}$ saturation. Further research is needed to estimate soil $\mathrm{N}_{2}$ fluxes (emission and fixation), which may amount up to several $\mathrm{kg} \mathrm{Nha}^{-1} \mathrm{yr}^{-1}$.
\end{abstract}

\section{Introduction}

Anthropogenic emissions of reactive nitrogen $(\mathrm{N})$ have markedly increased the atmospheric $\mathrm{N}$ deposition to forests, especially around industrialized regions (Pinho et al., 2012; Gruber and Galloway, 2008; Galloway et al., 2003). There is, however, a large spatial variability in the effects by $\mathrm{N}$ deposition (Magnani et al., 2007; Fischer et al., 2010). Forest ecosystems with slow $\mathrm{N}$ cycling and low or moderate atmospheric $\mathrm{N}$ deposition are called nitrogen limited, as their productivity is enhanced by the increased $\mathrm{N}$ inputs. Forest ecosystems with high deposition rates receive $\mathrm{N}$ in excess, which increases the outputs markedly. In such a case the ecosystems are called nitrogen saturated (Aber et al., 1998). Here we divide $\mathrm{N}$ cycling in forests into inputs, outputs and internal cycling. Inputs include atmospheric $\mathrm{N}$ deposition, fixation, and fertilization. Outputs include $\mathrm{N}$ losses in gaseous emissions and drainage flow. Internal cycling includes all the processes where $\mathrm{N}$ is transported within the ecosystem. The inputs and outputs of $\mathrm{N}$ to and from undisturbed forest ecosystems are small, and the internal cycling dominates the $\mathrm{N}$ flow (Mälkönen, 1974). The increased N deposition in turn affects the whole $\mathrm{N}$-cycling process in forest ecosystems.

In boreal forests, the inputs of $\mathrm{N}$ via atmospheric deposition and $\mathrm{N}_{2}$ fixation are relatively small, at maximum around $10 \mathrm{~kg} \mathrm{~N} \mathrm{ha}^{-1} \mathrm{yr}^{-1}$ (Flechard et al., 2011; Syri et al., 2004; Mustajärvi et al., 2008) and $0.1-3.5 \mathrm{~kg} \mathrm{~N} \mathrm{ha}^{-1} \mathrm{yr}^{-1}$ (DeLuca et al., 2002, 2008; Zackrisson et al., 2004, 2009), respectively. In these systems, the $\mathrm{N}$ outputs are reported to be small, both via leaching of ammonium $\left(\mathrm{NH}_{4}^{+}-\mathrm{N}\right)$, nitrate 
$\left(\mathrm{NO}_{3}-\mathrm{N}\right)$ and dissolved organic nitrogen (DON) into groundwater (Kubin, 1998), and through volatilization of oxidized nitrogen $\left(\mathrm{N}_{2} \mathrm{O}, \mathrm{NO}_{\mathrm{x}}\right)$ into the atmosphere (Pilegaard et al., 2006; Pihlatie et al., 2007; Maljanen et al., 2010). The soil emissions of $\mathrm{N}_{2}$ are highly uncertain as there are no measurements available from boreal ecosystems. In general, the total $\mathrm{N}$ inputs and outputs in boreal forests are markedly less than those in more $\mathrm{N}$-affected Central European forest ecosystems (Flechard et al., 2011; Holland et al., 2005). In boreal forests, $\mathrm{N}$ is reported to accumulate into the soil (Berg and Dise, 2004; Hattenschwiler and Vitousek, 2000) and biomass of growing trees.

According to the current knowledge, plants can take up $\mathrm{N}$ either in mineral $\left(\mathrm{NH}_{4}^{+}\right.$or $\mathrm{NO}_{3}^{-}$) or amino acid forms (e.g. Kielland et al., 2006). Nitrogen uptake by plants is affected by the availability of these compounds, released via decomposition, but also by the atmospheric $\mathrm{N}$ deposition and $\mathrm{N}_{2}$ fixation. Even though there are large pools of $\mathrm{N}$ in the boreal ecosystems, there is less $\mathrm{N}$ available for plant uptake than plants are able to consume. This is concluded from the fact that $\mathrm{N}$ fertilization tends to increase the productivity of boreal forests (Saarsalmi and Mälkönen, 2001). In boreal upland forests, the low $\mathrm{N}$ availability results from the cool climate and the chemical composition of soil organic matter. However, plants can reuse $\mathrm{N}$ efficiently because it is a mobile nutrient. A major fraction of the $\mathrm{N}$ that is being lost in senescing plant tissue can be resorbed and retranslocated when new tissue is grown.

As several studies recognize, the role and magnitude of organic $\mathrm{N}$ inputs to and outputs from the ecosystems and direct plant uptake has largely been overlooked (Kielland et al., 2007; Neff et al., 2002; Mustajärvi et al., 2008). Recent studies show that organic $\mathrm{N}$ can contribute as much as $30 \%$ of the total $\mathrm{N}$ deposition into ecosystems (Neff et al., 2002), and up to $80 \%$ of the total $\mathrm{N}$ lost as runoff (Mustajärvi et al., 2008). It seems evident that trees uptake $\mathrm{N}$ from soil directly as amino acids (Jones and Kielland, 2002; Kielland et al., 2007).

Here we present a measurement-based $\mathrm{N}$ budget of a boreal Scots pine forest in Southern Finland. We show the N budget based on a comprehensive data series covering the inputs, outputs, pools, and internal cycling of $\mathrm{N}$ within the forest ecosystem from 2006 to 2010 . We further calculate the individual sources of $\mathrm{N}$ for the plants and the total $\mathrm{N}$ atmospheric deposition. The study compliments the longterm measurements of carbon and water balances of the site, which are presented in Ilvesniemi et al. (2009, 2010), respectively.

\section{Materials and methods}

\subsection{Measurement site}

Measurements were conducted at a Scots pine stand at the SMEAR II station in Hyytiälä (Hari and Kulmala, 2005), Southern Finland $\left(61^{\circ} 51^{\prime} \mathrm{N}, 24^{\circ} 17^{\prime} \mathrm{E}\right)$. The mean annual air temperature and precipitation at Hyytiälä from 1971 to 2000 were $3.3^{\circ} \mathrm{C}$ and $713 \mathrm{~mm}$, respectively (Drebs et al., 2002). The stand is an even-aged forest, and it was regenerated by sowing after clear-cutting, prescribed burning, and soil preparation in 1962. The measurement station was established in 1995 . The stand was partially thinned from January to March 2002 (Vesala et al., 2005).

The dominant tree species is Scots pine, covering $93 \%$ of the stem basal area in the study area. Of the other tree species, mainly in the understorey, the most important are Norway spruce (Picea abies) and Silver birch (Betula pendula), contributing $2.6 \%$ and $1.1 \%$ of the total basal area, respectively. Other species in the understorey include rowan (Sorbus aucuparia), Grey alder (Alnus incana), Goat willow (Salix caprea) and Eurasian aspen (Populus tremula). The dominant species in the field layer are the shrubs Vaccinium myrtillus and Vaccinium vitis-idaea, and in the ground layer the mosses Dicranum polysetum and Pleurozium schreberi (Kulmala et al., 2008).

The soil at the site is Haplic podzol on glacial till (FAOUNESCO-ISRIC, 1988), overlaying homogeneous granite bedrock at an average of $0.6 \mathrm{~m}$ depth. The study area is defined as the area inside the borders of two mini-catchments $\left(\mathrm{C} 1,889 \mathrm{~m}^{2}\right.$, and $\left.\mathrm{C} 2,301 \mathrm{~m}^{2}\right)$ that receive water only from precipitation, since they are located at the top of a small hill (Fig. 1). The mini-catchment borders were mapped based on bedrock topography, and measured by soil penetrating radar in 1994. Two concrete weirs were built to guide the lateral outflow of water to outlets of the two weirs. The radar measurement showed that there were no major vertical cracks in the bedrock. The lowest soil layer on the bedrock has a high silt fraction, rendering the watershed water tight. Thus water flows in the soil along the direction of the slope and outflow occurs only via the outlets in the weirs as reported in Ilvesniemi et al. (2010).

\subsection{Nitrogen pools}

\subsubsection{Total and non-soluble nitrogen in soil}

The pool of $\mathrm{N}$ bound to the soil matrix (the non-soluble soil $\mathrm{N}$ pool) was calculated by subtracting extractable and soil water $\mathrm{N}$ pools from the total soil $\mathrm{N}$ pool.

The total soil $\mathrm{N}$ pool was determined from soil samples collected from different soil horizons in 1995. The samples were taken using steel cylinders $\left(148 \mathrm{~cm}^{3}\right.$ volume, $6 \mathrm{~cm}$ diameter) from each morphologic soil horizon $(\mathrm{L} / \mathrm{F} / \mathrm{H}$, eluvial E horizon, illuvial B horizon and parent material $\mathrm{C}$ horizon) 
from the vertical face of 5 soil pits. The samples were air dried at $60^{\circ} \mathrm{C}$, sieved through a $2 \mathrm{~mm}$ sieve, and ground before the analysis. The $\mathrm{C}$ and $\mathrm{N}$ contents of each sample were analyzed using an elemental CN analyzer (LECO, Leco Corporation, St. Joseph, MI, USA).

The $\mathrm{N}$ pool was calculated for each soil horizon and for each pit by using a horizon-specific average for each of the following: $\mathrm{N}$ concentration, horizon depth, soil density and stone fraction. The $\mathrm{N}$ pool for each soil horizon was calculated as the average of the $\mathrm{N}$ pools of the specific horizon in each pit. The total soil $\mathrm{N}$ pool was calculated as the sum of $\mathrm{N}$ pools of all horizons.

\subsubsection{Extractable nitrogen in soil}

The extractable pools of soil ammonium $\left(\mathrm{NH}_{4}^{+}-\mathrm{N}\right)$, nitrate $\left(\mathrm{NO}_{3}^{-}-\mathrm{N}\right)$ and organic nitrogen $\left(\mathrm{N}_{\text {org }}\right)$ were determined from samples taken from litter- and humus-layers and from mineral soil at $0-0.1 \mathrm{~m}$ and $0.1-0.3 \mathrm{~m}$ depths. The samples were collected with a Westman soil auger (Westman, 1995) 1 to 3 times per year (8 times in total) from 2006 to 2009. Fresh soil samples were extracted with $2 \mathrm{M} \mathrm{KCl}$ for $2 \mathrm{~h}$, and the extracts were filtered through Whatman 40 filter papers and frozen until analysis. Dissolved $\mathrm{NH}_{4}^{+}, \mathrm{NO}_{3}^{-}$and $\mathrm{N}_{\text {org }}$ in the extracts were analyzed by flow-injection spectrometry, as described in Sect. 2.3.2. Nitrogen pools on soil particle surfaces were estimated by subtracting $\mathrm{N}$ pools in soil water in the uppermost $0.3 \mathrm{~m}$ depth from the measured values of extractable $\mathrm{N}$ pools.

\subsubsection{Nitrogen in soil water}

The pools of $\mathrm{NH}_{4}^{+}-\mathrm{N}, \mathrm{NO}_{3}^{-}-\mathrm{N}$ and $\mathrm{N}_{\text {org }}$ in soil water were calculated by measuring the concentrations in every soil layer, and multiplying the measured concentrations with soil water storage specific to each soil horizon. Layer specific soil water pool was calculated based on time-domain reflectometry measurements, as described in Ilvesniemi et al. (2010). The concentrations of $\mathrm{NH}_{4}^{+}-\mathrm{N}, \mathrm{NO}_{3}^{-}-\mathrm{N}$ and $\mathrm{N}_{\text {org }}$ were measured in soil water samples obtained with suction cup lysimeters. Suction cups were installed at 7 locations (pits) and at each location in every soil horizon. Samples were collected in weekly to fortnightly intervals during the periods when the soil was not frozen. At the time of sampling, a suction pump ( -400 mbar) was applied to the tubes connected with suction cups in different soil depths. Water was sampled when either the water volume reached a minimum of $250 \mathrm{~mL}$, or after 7 to $34 \mathrm{~h}$ of collecting. During the summer months when the soil was relatively dry, even the 34-h collection did not provide sufficient amounts of water from all locations. To determine the ratio between nitrate and nitrite $\left(\mathrm{NO}_{3}^{-}: \mathrm{NO}_{2}^{-}\right)$in soil water, we used data measured in 1997. Nitrate $\left(\mathrm{NO}_{3}^{-}\right)$and nitrite $\left(\mathrm{NO}_{2}^{-}\right)$concentrations were measured colorimetrically from the drainage flow water by a nitrate reduction tube with cad- mium column (Dorich and Nelson, 1984). The water analysis is explained in Sect. 2.3.2.

\subsubsection{Aboveground biomass nitrogen}

To estimate $\mathrm{N}$ pools in aboveground biomass, the diameter at $1.3 \mathrm{~m}$ height and height of every tree in the catchment were measured. Regression functions described in Repola $(2008,2009)$ were used to model the dry weight of wood, stems, bark, needles, leaves, roots, alive branches, and dead branches. The dry weights of the biomass classes were then multiplied with the representative $\mathrm{N}$ concentrations, presented in Table 1 . The data of coniferous needles used in the regression were collected in the autumn, when part of the needles were already shed (Repola, 2009). Therefore the model gives an underestimation of the maximum foliage pool. As follows, $60 \%$ of the annual needle litter fall was added to the estimation, as based on the litter fall measurements on the site. This $60 \%$ represents the amount of needle litter fall occurring during the autumn.

Annual biomass $\mathrm{N}$ pool change $\left(\Delta B ; \mathrm{kg} \mathrm{N} \mathrm{ha}^{-1} \mathrm{yr}^{-1}\right)$ calculations were based on the difference between the biomass classes from 2003 and 2008. We consider the model results for the increase of wood and bark biomass to be relatively reliable, but we consider the biomass change in branches and foliage to be only suggestive, because the needle mass is usually assumed not to increase after the canopy has been closed.

\subsection{Nitrogen transport in water}

\subsubsection{Sampling and maintenance}

Bulk deposition, throughfall and stemflow waters were collected in canisters, which were changed monthly during the winter and once a fortnight during the summer, or whenever they were getting full. All of the canisters were always changed at the same time. The canisters were washed with hot water and Deconex ${ }^{\circledR}$ laboratory cleaning detergent (Borer Chemie AG, Zuchwil, Switzerland), rinsed with tap water three times, and finally rinsed twice with deionized water. Throughfall collectors were cleaned daily using a brush, deionized water, and washcloth to remove needles, pollen and other dirt. No anti-microbial substances were used in the canisters or the throughfall collectors. The water collecting system is described in more detail by Ilvesniemi et al. (2010).

\subsubsection{Laboratory water analyses}

The water samples (precipitation, throughfall, stemflow, soil water and drainage flow) were analyzed as follows: (1) the amount of collected water was measured by weighing $\left(1 \mathrm{~kg} \approx 1 \mathrm{dm}^{3}\right)$, (2) precipitation, throughfall and stemflow subsamples were each pooled into one sample (3) $\mathrm{pH}$ and electric conductivity were measured, (4) precipitation, throughfall, and stemflow samples were filtered with a vacuum-driven filtering system (Millipore) using $0.45 \mu \mathrm{m}$ 
membrane filters (Millipore), and (5) samples were bottled and stored at $-17^{\circ} \mathrm{C}$ until further analysis.

Ammonium $\left(\mathrm{NH}_{4}^{+}\right)$, nitrate $\left(\mathrm{NO}_{3}^{-}\right)$and organic nitrogen $\left(\mathrm{N}_{\text {tot }}\right)$ were measured from all the water samples and the soil extracts by flow-injection spectrometry at the Finnish Forest Research Institute, Vantaa Unit (modified ISO 11732:2005 (FIA), SFS-EN ISO 13395:1997: SFS-EN ISO 119051:1998 (FIA), respectively). Detection limits for $\mathrm{NH}_{4}^{+}-\mathrm{N}$, $\mathrm{NO}_{3}-\mathrm{N}$, and $\mathrm{N}_{\text {tot }}$ were $0.03,0.001$ and $0.1 \mathrm{mg} \mathrm{dm}^{-3}$, respectively. Organic $\mathrm{N}\left(\mathrm{N}_{\text {org }}\right)$ was determined using total $\mathrm{N}$ concentrations in the samples as follows:

$\left[\mathrm{N}_{\text {org }}\right]=\left[\mathrm{N}_{\text {tot }}\right]-\left[\mathrm{NH}_{4}^{+}-\mathrm{N}\right]-\left[\mathrm{NO}_{3}^{-}-\mathrm{N}\right]$.

The filtering of the soil extracts with Whatman 40 filter paper $(8 \mu \mathrm{m})$ does not remove all the particulate $\mathrm{N}$. Therefore, we recognize that the $\mathrm{N}_{\text {org }}$ includes both dissolved organic nitrogen and some particulate $\mathrm{N}$.

\subsubsection{Stemflow}

Stemflow was measured from 2006 to 2009 during snow-free periods from 4 trees by directing stemflow water into insulated canisters. For that purpose cleaved silicon rubber tubes (diameter $25 \mathrm{~mm}$ ) were attached around the trees. The $\mathrm{N}$ flux rate in separate chemical $\mathrm{N}$ forms $\left(\mathrm{NH}_{4}^{+}-\mathrm{N}, \mathrm{NO}_{3}^{-}-\mathrm{N}, \mathrm{N}_{\text {org }}\right)$ in stemflow $\left(S_{\mathrm{c}} ; \mathrm{mg} \mathrm{N} \mathrm{m}^{-2} \mathrm{day}^{-1}\right)$ in the forest was calculated as follows:

$S_{\mathrm{c}}=\frac{1}{4} \sum_{i=1}^{4} \frac{A_{\mathrm{btot}}}{A_{\mathrm{b} i}} \frac{C_{c i} V_{c i}}{\left(A_{\mathrm{C} 1}+A_{\mathrm{C} 2}\right) t}$,

where "c" refers to the chemical forms of $\mathrm{N}, i$ refers to a measured tree, 4 is the number of measured trees, $C_{\mathrm{ci}}$ is the concentration of $\mathrm{N}\left(\mathrm{mg} \mathrm{dm}^{-3}\right)$ in the stem flow water in different chemical forms $\left(\mathrm{NO}_{3}^{-}-\mathrm{N}, \mathrm{NH}_{4}^{+}-\mathrm{N}, \mathrm{N}_{\text {org }}\right), V_{\text {ci }}$ is the volume of the collected stem flow water $\left(\mathrm{dm}^{3}\right), A_{\mathrm{b} i}$ is the stem cross section area of the trees from where the stem flow was measured, $A_{\mathrm{b} \text { tot }}$ is the total stem cross section area of the trees in the catchments $\left(\mathrm{m}^{2} ; \mathrm{C} 1+\mathrm{C} 2\right), A_{\mathrm{C} 1}$ and $A_{\mathrm{C} 2}$ are the areas of the two micro-catchment areas $\left(\mathrm{m}^{2}\right)$ described in Sect. 2.1, and $t$ is the length of the collection period (in days).

\subsubsection{Drainage flow}

As described in Sect. 2.1, the study site is defined as the area inside two micro-catchments, and the outflow water is directed to the two weirs. The water flow through the weirs was measured automatically with a flow meter (Schlumberger Aquatic, Schlumberger Water Services, Paris, France), and when flow existed, water was sampled for chemical analysis on a daily basis from the outlet of the weirs. The daily sum of water flow was multiplied with the concentrations of different chemical forms of $\mathrm{N}\left(\mathrm{NH}_{4}^{+}-\mathrm{N}, \mathrm{NO}_{3}^{-}-\mathrm{N}, \mathrm{N}_{\text {org }}\right)$ to get the daily $\mathrm{N}$ fluxes separately. When the concentrations were under the detection limit, we used half of the detection limit as the measured value. We also calculated the lower and the upper values for the $\mathrm{N}$ flux in the drainage flow by assuming that the lower value was zero and that the upper value was the detection limit. The lower and upper values were used to calculate the uncertainty for the average flux. The drainage flow measurements are explained in more detail in Ilvesniemi et al. (2010).

\subsection{Atmospheric N deposition}

The total annual $\mathrm{N}$ deposition to the site was calculated as the sum of estimated wet and dry deposition. Wet deposition was estimated from the measured bulk deposition data, and the values for dry deposition were taken from Flechard et al. (2011).

\subsubsection{Bulk deposition}

Different $\mathrm{N}$ components $\left(\mathrm{NO}_{3}^{-}, \mathrm{NH}_{4}^{+}, \mathrm{N}_{\text {org }}\right)$ in the bulk $\mathrm{N}$ deposition were sampled in a tower above the forest canopy using two rain water collectors made of polyethylene funnels $\left(0.13 \mathrm{~m}^{2}\right.$ in area; Plastex Oy, Lohja, Finland). In the winter, snowfall was collected into circular canisters $\left(0.2 \mathrm{~m}^{2}\right.$ in area). The canisters were changed monthly in winter and once a fortnight in summer, or whenever they were getting full. No anti-microbial substances were used in the canisters. The bulk deposition rate was calculated by multiplying measured concentrations of $\mathrm{NO}_{3}^{-}, \mathrm{NH}_{4}^{+}$and $\mathrm{N}_{\text {org }}$ by precipitation and dividing by collection time. The precipitation was measured optically with a DRD12 rain detector (Vaisala Oyj, Helsinki, Finland). The water collecting system is described in more detail by Ilvesniemi et al. (2010).

\subsubsection{Throughfall}

Throughfall water was collected using seven rectangular rainwater collectors installed below the forest canopy at approximately $0.5 \mathrm{~m}$ height from soil surface. The collectors were made of stainless steel and were $4 \mathrm{~m}$ long and $0.1 \mathrm{~m}$ wide, with effective water collecting area $\left(A_{t}\right)$ being $0.385 \mathrm{~m}^{2}$. Throughfall waters were collected in insulated canisters installed below the midpoint of each collector. During the winter, when precipitation was dominated by snowfall, the throughfall collectors were replaced with circular canisters $\left(0.2 \mathrm{~m}^{2}\right)$.

Throughfall rates $\left(T_{\mathrm{c}} ; \mathrm{mg} \mathrm{N} \mathrm{m}^{-2} \mathrm{~d}^{-1}\right)$ were calculated as follows:

$T_{\mathrm{c}}=\frac{c_{t \mathrm{c}} V_{t}}{A_{t} t}$,

where subscript " $\mathrm{c}$ " refers to the concentration of $\mathrm{N}$ stored in different chemical forms $\left(\mathrm{NO}_{3}^{-}, \mathrm{NH}_{4}^{+}\right.$or $\left.\mathrm{N}_{\text {org }}\right), c_{t \mathrm{c}}$ is the concentration of the compound in the water sample $\left(\mathrm{mg} \mathrm{dm}^{-3}\right)$, $V_{t}$ is the volume of the water sample $\left(\mathrm{dm}^{3}\right), A_{t}$ is area of the collector, and $t$ is the length of the collection period (days). 


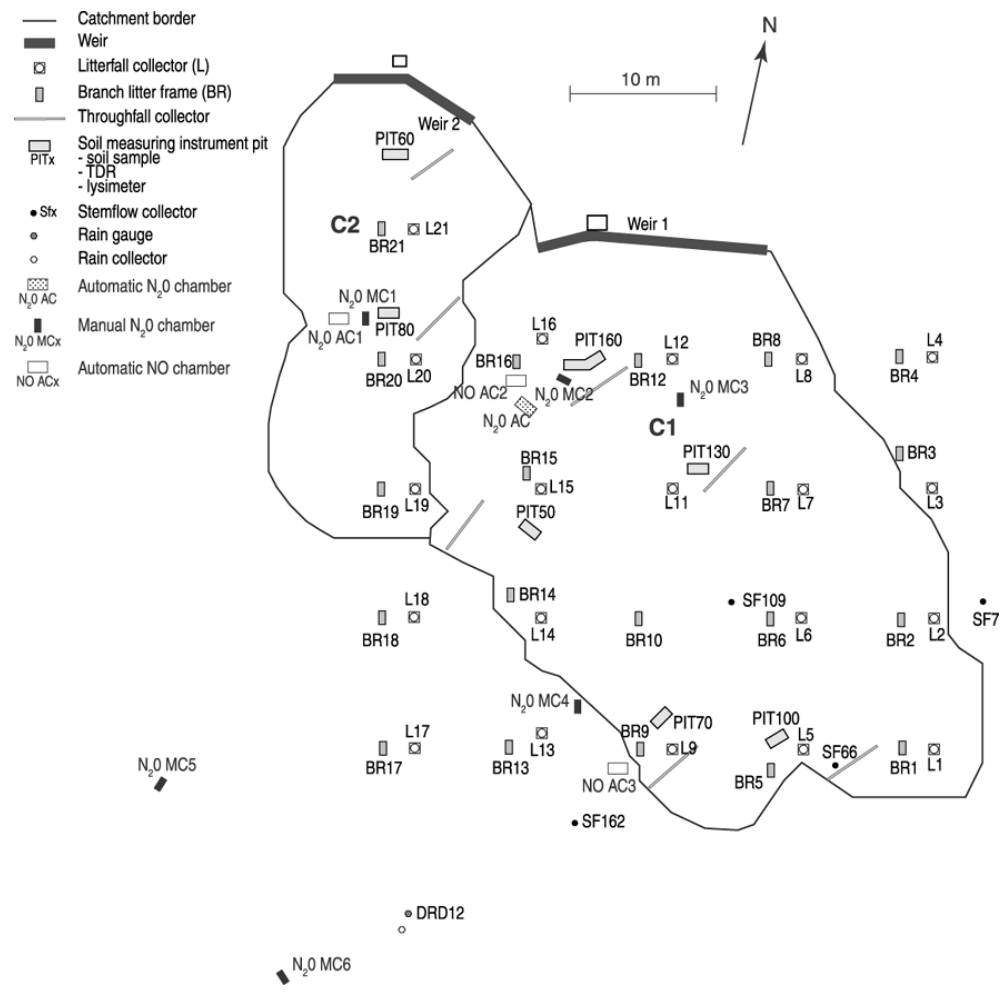

Fig. 1. Map of the measurement site indicating the sampling design for measuring nitrogen fluxes in precipitation, throughfall, stemflow, litter fall, drainage flow, $\mathrm{NO}$ - and $\mathrm{N}_{2} \mathrm{O}$-emissions and nitrogen pools in the soil water. The two catchment areas $(\mathrm{C} 1, \mathrm{C} 2)$ are marked on the map with a line, and the drainage flow is directed to the two weirs on top of the map. The height and the diameter at $1.3 \mathrm{~m}$ of every tree in the catchment areas were measured for biomass inventory.

\subsubsection{Estimating wet deposition from bulk deposition measurement}

The bulk deposition measurement gives an underestimation of the total (wet + dry) deposition, and an overestimation to the wet deposition. This is due to the fact that in the bulk deposition measurement, some but not all of the dry deposition is included. A simple model to fractionate the bulk deposition into wet and dry deposition was formulated based on the amount of precipitation and the period of time during which the dry deposition could have occurred. As the result, the model gives an estimate of wet nutrient deposition of the ecosystem. The model also gives an estimation of the dry deposition, but only of the deposition on the bulk deposition collector, not the deposition of the whole ecosystem. As a result of the model, we get that the wet deposition was $57 \%$ of the measured bulk deposition. To calculate the total wet deposition at the site, the amount of bulk deposition was multiplied by this number $(57 \%)$. The model is described briefly in Korhonen et al. (2012).

\subsubsection{Dry deposition}

The mean of the dry deposition of four models presented in Flechard et al. (2011) for Hyytiälä were used as an estimate of the dry deposition. When this dry deposition data was used in conjunction with the measured bulk deposition data from this study, the modeled aerosol particle $\mathrm{NH}_{4}^{+}$and gaseous $\mathrm{NH}_{3}^{+}$deposition were coupled with the measured $\mathrm{NH}_{4}^{+}$deposition, and modeled aerosol particle $\mathrm{NO}_{3}^{-}$and gaseous $\mathrm{NO}_{2}$ and $\mathrm{HNO}_{3}$ deposition were coupled with the measured $\mathrm{NO}_{3}^{-}$ deposition.

\subsection{Gaseous emissions}

\subsubsection{Nitrous oxide $\left(\mathrm{N}_{2} \mathrm{O}\right)$}

The fluxes of nitrous oxide $\left(\mathrm{N}_{2} \mathrm{O}\right)$ were measured with one automatic and six manual static chambers. The automatic chamber and four of the manual chambers were located in the two catchment areas, whereas two manual chambers were located outside the catchment (Fig. 1). The automatic chamber was made of stainless steel $(0.40 \times 0.80 \times 0.32 \mathrm{~m}$ : width $\times$ length $\times$ height), and was equipped with two fans and a thermocouple for chamber air temperature measurement. The chamber was automatically closed 1-4 times per day for $60 \mathrm{~min}$. During each enclosure a minimum of 4 gas samples were withdrawn from the headspace by a custommade autosampler (MaSa, Pohja-Metallityöpaja, Juupajoki, Finland). The manual chambers were made of stainless-steel 
Table 1. Nitrogen concentrations of aboveground biomass classes used for biomass nitrogen pool calculations. The wood concentration was measured in Juupajoki, near the measurement site.

\begin{tabular}{|c|c|c|c|}
\hline Biomass class & $\begin{array}{r}\mathrm{N} \\
\left(\mathrm{mg} \mathrm{g}^{-1}\right)\end{array}$ & Description & Reference \\
\hline Wood & 0.72 & Literature & $\begin{array}{l}\text { Mälkönen } \\
\text { (1974) }\end{array}$ \\
\hline $\begin{array}{l}\text { Scots pine } \\
\text { needles }\end{array}$ & 12 & $\begin{array}{l}\text { Measured } \\
\text { on site }\end{array}$ & $\begin{array}{l}\text { Palmroth and Hari } \\
\text { (2001) }\end{array}$ \\
\hline $\begin{array}{l}\text { Norway spruce } \\
\text { needles }\end{array}$ & 11 & Literature & $\begin{array}{l}\text { Braekke et al. } \\
\text { (1998) }\end{array}$ \\
\hline $\begin{array}{l}\text { Broad-leaved } \\
\text { species }\end{array}$ & 24 & Literature & $\begin{array}{l}\text { Berg and } \\
\text { McClaugherty (2003) }\end{array}$ \\
\hline Bark & 4.2 & $\begin{array}{l}\text { Measured } \\
\text { on site }\end{array}$ & $\begin{array}{l}\text { Litter trap data } \\
\text { (this study) }\end{array}$ \\
\hline Branches & 1.3 & $\begin{array}{l}\text { Measured } \\
\text { on site }\end{array}$ & $\begin{array}{l}\text { Litter trap data } \\
\text { (this study) }\end{array}$ \\
\hline
\end{tabular}

$(0.29 \times 0.40 \times 0.24)$, and they were equipped with a fan and a sample port in the middle of the chamber (Pihlatie et al., 2007).

The manual chamber measurements were conducted on a weekly basis during summer months and monthly in the winter as described by Pihlatie et al. (2007). The concentrations of $\mathrm{N}_{2} \mathrm{O}$ in the gas samples were analyzed by a gas chromatograph equipped with an electron capture detector. $\mathrm{N}_{2} \mathrm{O}$ fluxes were calculated by linear regression method. Non-linearity of the concentration change over chamber closures was tested. Due to measuring $\mathrm{N}_{2} \mathrm{O}$ fluxes close to the detection limit (see Pihlatie et al., 2007), we chose to use the linear regression method as the more robust calculation method for the $\mathrm{N}_{2} \mathrm{O}$ fluxes.

\subsubsection{Nitrogen oxide (NO)}

Flux of NO from the soil was measured using three automatic dynamic flow-through chambers during a short campaign from 15 July to 30 October 2011. The chambersystem consisted of three transparent chambers similar to the automatic $\mathrm{N}_{2} \mathrm{O}$ chamber, and with fluorinated ethylenepropylene film as the transparent wall material. The operation of the chambers was automated; each chamber was closed for $15 \mathrm{~min}$ once every three hours. Sample air was drawn from the chambers at a rate of $4.1 \mathrm{dm}^{3} \mathrm{~min}^{-1}$ into a chemiluminescence analyser (TEI 42S, Thermo Environmental Instruments, Philadelphia, PA, USA). The measurement principle for the soil NO flux was similar to that of the shoot $\mathrm{NO}_{\mathrm{x}}$ flux described in Raivonen et al. (2003), except that an empty chamber was not used as a reference chamber. At the time of the sampling, compensation air from the above canopy atmosphere was directed into the chambers at a rate of $4.5 \mathrm{dm}^{3} \mathrm{~min}^{-1}$. Soil flux was calculated using a flux calculation method for flow through chambers as described in Kolari et al. (2012).
Table 2. Nitrogen and carbon contents and carbon-to-nitrogenratios in the annual litter fall, and in different litter fractions in Scots pine forest at Hyytiälä during 2006 to 2008. "Cones and seeds" represents all the material distinguished as reproductive material, but it mostly consists of cones. Uncertainty is standard error of the annual means.

\begin{tabular}{lrrr}
\hline & $\mathrm{C} \mathrm{mg} \mathrm{g}^{-1}$ & $\mathrm{~N} \mathrm{mg} \mathrm{g}^{-1}$ & $\mathrm{C}: \mathrm{N}$ \\
\hline Needles & $512 \pm 3$ & $4.9 \pm 0.3$ & $104 \pm 7$ \\
Leaves & $486 \pm 4$ & $8.8 \pm 0.7$ & $55 \pm 5$ \\
Large branches & $499 \pm 0$ & $4.7 \pm 0.1$ & $105 \pm 1$ \\
Small branches & $494 \pm 2$ & $4.4 \pm 0.3$ & $113 \pm 7$ \\
Bark & $492 \pm 6$ & $3.7 \pm 0.2$ & $134 \pm 6$ \\
Cones and seeds & $471 \pm 3$ & $2.1 \pm 0.2$ & $221 \pm 18$ \\
Other & $503 \pm 3$ & $12 \pm 1$ & $41 \pm 2$ \\
Total & $502 \pm 3$ & $5.1 \pm 0.3$ & $99 \pm 6$ \\
\hline
\end{tabular}

\subsection{Internal cycling}

\subsubsection{Litter fall}

Litter fall was measured monthly from 2006 to 2010 using 20 circular litter collectors $\left(0.2 \mathrm{~m}^{2}\right.$ each) installed systematically on the two catchment areas (Fig. 1) as described in Ilvesniemi et al. (2009). The litter collectors were emptied once a month, dried at $60^{\circ} \mathrm{C}$ for $24 \mathrm{~h}$, and weighed. Dried litter was then separated into needles, leaves, bark, branches, seeds (including cones), and remaining material. Each compartment was weighed, ground, and pooled. Carbon and $\mathrm{N}$ concentrations were measured from the pooled samples by elemental CN analyzer (vario Max CN, Elementar Analysensysteme $\mathrm{GmbH}$, Hanau, Germany). The N concentrations of litter fractions are presented in Table 2. Larger branch litter was collected into 20 frames $(0.5 \times 1.0 \mathrm{~m})$ lying on the ground. The branches were collected once a year and treated similarly as the other litter. The $\mathrm{N}$ flux in litter fall $\left(L ; \mathrm{g} \mathrm{N} \mathrm{m}^{-2} \mathrm{yr}^{-1}\right)$ is

$L=\frac{1}{20} \sum_{i=1}^{20}\left(m_{\mathrm{ci}} C_{\mathrm{c}}\right) \frac{1}{A_{L} t}$,

where $i$ refers to the number of the litter collectors or the branch frames, "c" refers to different biomass compartments, $m_{\mathrm{ci}}$ is the mass of collected litter compartment $(\mathrm{g}), C_{\mathrm{c}}$ is N concentration $\left(\mathrm{mg} \mathrm{N} \mathrm{g}^{-1}\right), A_{L}$ is the area of the collector, and $t$ is the length of collection period (in days).

\subsubsection{Nitrogen retranslocation and senescence}

Based on Helmisaari (1992), retranslocation of $\mathrm{N}(R$; $\mathrm{kg} \mathrm{Nha}^{-1} \mathrm{yr}^{-1}$ ) was calculated as follows:

$R=\frac{1.49 m_{\mathrm{b}} c_{\mathrm{g}}-m_{\mathrm{b}} c_{\mathrm{b}}}{A_{L} t_{r}}$,

where $m_{\mathrm{b}}$ is the mass of (brown) foliage litter collected by litter traps per year $(\mathrm{g}), c_{\mathrm{b}}$ is the $\mathrm{N}$ concentration of that litter 
$\left(\mathrm{mg} \mathrm{g}^{-1}\right), c_{\mathrm{g}}$ is $\mathrm{N}$ concentration of green needles $\left(12 \mathrm{mg} \mathrm{g}^{-1}\right.$; Palmroth and Hari, 2001), $A_{L}$ is the area of the litter collector, $t_{r}$ is the litter collection time $(1 \mathrm{yr}), 1.49$ is the relative mass of a single green needle to a single brown needle, calculated as an average from the three plots from various years $(n=11)$ presented by Helmisaari (1992). This number was applied to all tree species.

Plant $\mathrm{N}$ loss during senescence $\left(S ; \mathrm{kg} \mathrm{Nha}^{-1} \mathrm{yr}^{-1}\right.$ ) was calculated as the sum of litter fall and retranslocation. For all biomass classes other than foliage, retranslocation was assumed to be negligible. We assumed that the pool of dead plant material attached to the trees does not change, and thus that the values for $\mathrm{N}$ loss in the litter fall represent the $\mathrm{N}$ loss in senescence.

\subsection{Variables based on mass balance calculations}

The total $\mathrm{N}$ balance of the ecosystem $\left(\Delta \mathrm{N}_{\mathrm{s}}+\Delta \mathrm{N}_{\mathrm{b}}\right.$; $\mathrm{kg} \mathrm{Nha}^{-1} \mathrm{yr}^{-1}$ ) was calculated as follows:

$\Delta \mathrm{N}_{\mathrm{s}}+\Delta \mathrm{N}_{\mathrm{b}}=D_{\mathrm{w}}+D_{\mathrm{d}}-E_{\mathrm{N}_{2} \mathrm{O}}-E_{\mathrm{NO}}-D_{\mathrm{f}}$

where $\Delta \mathrm{N}_{\mathrm{s}}$ is the change of $\mathrm{N}$ pools in the soil, $\Delta N_{\mathrm{b}}$ is the change of $\mathrm{N}$ pool in aboveground biomass, $D_{\mathrm{w}}$ is the wet $\mathrm{N}$ deposition, $D_{\mathrm{d}}$ is the dry $\mathrm{N}$ deposition, $E_{\mathrm{N}_{2} \mathrm{O}}$ and $E_{\mathrm{NO}}$ are the $\mathrm{N}$ losses in $\mathrm{N}_{2} \mathrm{O}$ and $\mathrm{NO}$ emissions, respectively, and $D_{\mathrm{f}}$ is $\mathrm{N}$ loss in the drainage flow.

The amount of $\mathrm{N}$ used for growth $\left(Y_{i} ; \mathrm{kg} \mathrm{N} \mathrm{ha}^{-1} \mathrm{yr}^{-1}\right)$ was calculated as follows:

$Y_{i}=\Delta B_{i}+S_{i}$,

where $\Delta B_{i}$ is the change of $\mathrm{N}$ in biomass and $S_{i}$ is the senescence in the biomass class, both measured in $\mathrm{kg} \mathrm{N} \mathrm{ha}^{-1} \mathrm{yr}^{-1}$ and where subscript $i$ refers to the aboveground biomass class (needles, leaves, branches, bark, wood). The total amount of $\mathrm{N}$ used by plants $\left(B_{\mathrm{tot}} ; \mathrm{kg} \mathrm{Nha}^{-1} \mathrm{yr}^{-1}\right.$ ) was calculated as the sum of $\mathrm{N}$ used for each individual aboveground biomass class.

Nitrogen uptake by plants $\left(U ; \mathrm{kg} \mathrm{Nha}^{-1} \mathrm{yr}^{-1}\right)$ was calculated as follows:

$U=B_{\mathrm{tot}}-R$,

where $B_{\text {tot }}$ is $\mathrm{N}$ use by plants and $R$ is the retranslocation of $\mathrm{N}$.

Net release of $\mathrm{N}$ from the decomposition $\left(R_{\mathrm{d}} ; \mathrm{kg} \mathrm{Nha}^{-1} \mathrm{yr}^{-1}\right)$ was calculated by assuming that the pool of plant-available- $\mathrm{N}$ is constant in a time scale of a couple of years as follows:

$R_{\mathrm{d}}=U+E_{\mathrm{tot}}+D_{\mathrm{f}}-D_{\mathrm{tot}}$,

where $U$ is $\mathrm{N}$ uptake by plants, $E_{\text {tot }}$ is the gas emission of $\mathrm{N}$ $\left(E_{\mathrm{N}_{2} \mathrm{O}}+E_{\mathrm{NO}}\right), D_{\mathrm{f}}$ is the drainage flow and $D_{\text {tot }}$ is the total deposition $\left(D_{\mathrm{w}}+D_{\mathrm{d}}\right)$, all in $\mathrm{kg} \mathrm{Nha}^{-1} \mathrm{yr}^{-1}$.
Table 3. Nitrogen concentrations, nitrogen pools and carbon-tonitrogen ratios in different physical soil horizons $(\mathrm{O}, \mathrm{A}, \mathrm{B}, \mathrm{C} 1$ and C2). The average depth of the mineral soil is $0.59 \mathrm{~m}$.

\begin{tabular}{lrrrrr}
\hline & $\mathrm{O}$ & $\mathrm{A}$ & $\mathrm{B}$ & $\mathrm{C} 1$ & $\mathrm{C} 2$ \\
\hline Horizon thickness (m) & 0.05 & 0.041 & 0.16 & 0.19 & 0.20 \\
$\mathrm{~N}$ concentration $\left(\mathrm{mg} \mathrm{g}^{-1}\right)$ & 13 & 1.2 & 1.0 & 0.17 & 0.053 \\
$\mathrm{~N}$ pool $\left(\mathrm{kg} \mathrm{N} \mathrm{ha}^{-1}\right)^{*}$ & 710 & 240 & 860 & 190 & 75 \\
$\mathrm{C}: \mathrm{N}$ & 28 & 33 & 23 & 36 & 19 \\
\hline
\end{tabular}

$* 1 \mathrm{ha}=10000 \mathrm{~m}^{2}$.

The change of the non-soluble soil $\mathrm{N}$ pool $\left(\Delta \mathrm{N}_{\text {som }}\right.$; $\mathrm{kg} \mathrm{N} \mathrm{ha}^{-1} \mathrm{yr}^{-1}$ ) was calculated as follows:

$\Delta \mathrm{N}_{\mathrm{som}}=L-R_{\mathrm{d}}$,

where $L$ is $\mathrm{N}$ flux in the litter fall and $R_{\mathrm{d}}$ is the net release of $\mathrm{N}$ from the decomposition, both in $\mathrm{kg} \mathrm{Nha}^{-1} \mathrm{yr}^{-1}$.

\section{Results}

\subsection{Soil nitrogen pools}

The total $\mathrm{N}$ pool in the soil was $2070 \mathrm{~kg} \mathrm{Nha}^{-1}$ $\left(1 \mathrm{ha}^{-1}=10000 \mathrm{~m}^{-2}\right)$. The vast majority of the soil $\mathrm{N}$ was bound to the soil matrix $\left(2050 \mathrm{~kg} \mathrm{~N} \mathrm{ha}^{-1}\right)$. The organic layer (litter and humus) and the uppermost $0.2 \mathrm{~m}$ mineral soil horizons (A and B horizons) contained 710 and $1100 \mathrm{~kg} \mathrm{~N} \mathrm{ha}^{-1}$, respectively, which comprised $87 \%$ of the total soil $\mathrm{N}$ (Table 3). The highest $\mathrm{N}$ concentration in the soil was in the organic layer, $12.9 \mathrm{mg} \mathrm{g}^{-1}$ of soil. In the mineral soil the $\mathrm{N}$ concentration was on the order of $1 \mathrm{mg} \mathrm{g}^{-1}$ in the $\mathrm{A}$ and $\mathrm{B}$ horizons, and on the order of $0.1 \mathrm{mg} \mathrm{g}^{-1}$, in the $\mathrm{C} 1$ and $\mathrm{C} 2$ horizons. The calculated soil non-soluble $\mathrm{N}$ accumulation rate $\left(\Delta \mathrm{N}_{\text {som }}\right)$ was $-1 \mathrm{~kg} \mathrm{Nha}^{-1} \mathrm{yr}^{-1}$, suggesting a slight decrease in the soil $\mathrm{N}$ pool. However, the estimation does not differ from 0 , taking into account the error margin $\left( \pm 8 \mathrm{~kg} \mathrm{Nha}^{-1} \mathrm{yr}^{-1}\right)$.

The extractable $\mathrm{N}$ pool in the organic layer and the topmost $0.30 \mathrm{~m}$ of the mineral soil $\left(26.8 \mathrm{~kg} \mathrm{Nha}^{-1}\right)$ was small compared to the total soil $\mathrm{N}$ pool. Of the extractable soil $\mathrm{N}$ almost all (98.9\%) was in organic form $\left(\mathrm{N}_{\mathrm{org}}\right), 26.5 \mathrm{~kg} \mathrm{~N} \mathrm{ha}^{-1}$. The vast majority of the mineral $\mathrm{N}$ was ammonium- $\mathrm{N}\left(\mathrm{NH}_{4}^{+}\right.$$\mathrm{N} ; 0.31 \mathrm{~kg} \mathrm{Nha}^{-1} ; 99.4 \%$ ), and only a minor fraction was nitrate- $\mathrm{N}\left(\mathrm{NO}_{3}^{-}-\mathrm{N} ; 2 \mathrm{~g} \mathrm{~N} \mathrm{ha}^{-1} ; 0.6 \%\right)$. The nitrate-N estimation is relatively uncertain.

$\mathrm{N}$ pool in soil water was $0.70 \mathrm{~kg} \mathrm{Nha}^{-1}$, and similar to the extractable $\mathrm{N}$, the majority of it was in organic form $\left(0.66 \mathrm{~kg} \mathrm{Nha}^{-1}\right)$. Ammonia and $\mathrm{NO}_{3}^{-}$pools in the soil water were approximately 30 and $3 \mathrm{~g} \mathrm{~N} \mathrm{ha}^{-1}$, respectively. $\mathrm{Ni}-$ trate concentrations were typically under the detection limit, and thus the extractable and especially soil water $\mathrm{NO}_{3}^{-}$pool sizes are uncertain. A more reliable estimation was obtained from the extracted $\mathrm{NO}_{3}^{-}$concentration, which includes both 
Table 4. The measured atmospheric annual bulk N deposition, estimated annual wet $\mathrm{N}$ deposition and modeled annual dry $\mathrm{N}$ deposition, all in $\mathrm{kg} \mathrm{Nha}^{-1} \mathrm{yr}^{-1}$ ).

\begin{tabular}{lrrrr}
\hline & $\mathrm{NH}_{4}^{+}$ & $\mathrm{NO}_{3}^{-}$ & $\mathrm{N}_{\text {org }}$ & Total \\
\hline Measured bulk deposition & 1.3 & 2.1 & 1.5 & 4.9 \\
Estimated wet deposition & 0.7 & 1.2 & 0.9 & 2.8 \\
Modeled/estimated dry deposition & $1.0^{*}$ & $2.5^{*}$ & 1.1 & 4.6 \\
Estimated total deposition & 1.7 & 3.7 & 2 & 7.4 \\
Measured throughfall & 0.5 & 1.1 & 1.4 & 3.0 \\
\hline
\end{tabular}

* Flechard et al. (2011); $\mathrm{NH}_{4}^{+}$and $\mathrm{NH}_{3}$ are combined as $\mathrm{NH}_{4}^{+}$, and $\mathrm{NO}_{3}^{-}, \mathrm{NO}_{2}$ and $\mathrm{HNO}_{3}$ are combined as $\mathrm{NO}_{3}^{-}$. Organic $\mathrm{N}$ deposition was not included in the study.

$\mathrm{NO}_{3}^{-}-\mathrm{N}$ in soil particle surfaces and in soil water. Based on the measurements in 1997, the median and mean ratios between nitrate and nitrite $\left(\mathrm{NO}_{3}^{-}: \mathrm{NO}_{2}^{-}\right)$in the drainage water measurements were 9.3 and 7.4 , respectively.

\subsection{Biomass nitrogen pools}

Nitrogen stored in the aboveground tree biomass in 2008 was $210 \mathrm{~kg} \mathrm{Nha}^{-1}$, which was $9 \%$ of the total $\mathrm{N}$ in the ecosystem. Nitrogen was distributed quite evenly to foliage $\left(77 \mathrm{~kg} \mathrm{Nha}^{-1}\right)$, branches $\left(58 \mathrm{~kg} \mathrm{Nha}^{-1}\right)$, wood $\left(49 \mathrm{~kg} \mathrm{Nha}^{-1}\right)$ and bark $\left(24 \mathrm{~kg} \mathrm{Nha}^{-1}\right)$. Of the branch $\mathrm{N}$ pool, $12 \mathrm{~kg} \mathrm{Nha}^{-1}$ was estimated to be stored in dead branches.

The total $\mathrm{N}$ accumulation to aboveground biomass was $7.4 \mathrm{~kg} \mathrm{Nha}^{-1} \mathrm{yr}^{-1}$. The wood and bark biomass increase were 2.3 and $0.8 \mathrm{~kg} \mathrm{Nha}^{-1} \mathrm{yr}^{-1}$, respectively. The more uncertain estimates for foliage and branch biomass accumulation were 1.8 and $2.6 \mathrm{~kg} \mathrm{~N} \mathrm{ha}^{-1} \mathrm{yr}^{-1}$, respectively.

\subsection{Atmospheric $\mathrm{N}$ deposition and throughfall}

Most of the total atmospheric deposition ( $\left.7.4 \mathrm{~kg} \mathrm{Nha}^{-1} \mathrm{yr}^{-1}\right)$ occurred in the form of dry deposition $\left(4.6 \mathrm{~kg} \mathrm{~N} \mathrm{ha}^{-1} \mathrm{yr}^{-1}\right)$. Most of the total deposition was in mineral form, but organic deposition contributed over one fourth of the total deposition. Between 2006 and 2010 the annual measured bulk $\mathrm{N}$ deposition varied from 4.0 to $6.3 \mathrm{~kg} \mathrm{Nha}^{-1} \mathrm{yr}^{-1}$, the mean bulk $\mathrm{N}$ deposition being $4.9 \mathrm{~kg} \mathrm{Nha}^{-1} \mathrm{yr}^{-1}$. The distribution of the deposition is described in Table 4.

The measured throughfall of $\mathrm{N}$ was $2.9 \mathrm{~kg} \mathrm{Nha}^{-1} \mathrm{yr}^{-1}$, which consisted mostly of $\mathrm{N}_{\text {org }}$ and $\mathrm{NO}_{3}^{-}-\mathrm{N}, 1.4$ and $1.1 \mathrm{~kg} \mathrm{Nha}^{-1} \mathrm{yr}^{-1}$, respectively. The measured $\mathrm{N}$ flux in stemflow, $0.1 \mathrm{~kg} \mathrm{Nha}^{-1} \mathrm{yr}^{-1}$, was very low compared to throughfall, and consisted mainly of $\mathrm{N}_{\text {org }}$. The measured concentrations of $\mathrm{NH}_{4}^{+}$and $\mathrm{NO}_{3}^{-}$were $25 \%$ to $90 \%$ higher in bulk deposition than in throughfall, but the concentration of $\mathrm{N}_{\text {org }}$ was on average $33 \%$ higher in throughfall than in bulk deposition. However, the measured throughfall flux was on average lower than the measured bulk deposition for mineral $\mathrm{N}$ and $\mathrm{N}_{\text {org. }}$.

\subsection{Drainage flow and gaseous emissions}

Annual $\mathrm{N}$ flux from the ecosystem via drainage flow varied between 0.04 and $0.23 \mathrm{~kg} \mathrm{Nha}^{-1} \mathrm{yr}^{-1}$ and was on average $0.13 \mathrm{~kg} \mathrm{~N} \mathrm{ha}^{-1} \mathrm{yr}^{-1}$. The $\mathrm{N}$ flux in drainage flow was dominated by $\mathrm{N}_{\text {org }}$, on average $0.12 \mathrm{~kg} \mathrm{Nha}^{-1} \mathrm{yr}^{-1}$. The average flux of mineral $\mathrm{N}$ in drainage flow was very low, $0.005 \mathrm{~kg} \mathrm{Nha}^{-1} \mathrm{yr}^{-1}$ and $0.002 \mathrm{~kg} \mathrm{~N} \mathrm{ha}^{-1} \mathrm{yr}^{-1}$ for $\mathrm{NH}_{4}^{+}$and $\mathrm{NO}_{3}^{-}$, respectively. The uncertainty for the mineral $\mathrm{N}$ values is approximately $\pm 50 \%$, and for the organic $\mathrm{N}$ up to $\pm 90 \%$. The uncertainty is primarily caused by the fact that the fluxes were very small and most of the time the $\mathrm{N}$ concentrations were below the detection limit. Therefore, it is more likely that our estimate of the drainage flow is an overestimation than an underestimation.

Both $\mathrm{N}_{2} \mathrm{O}$ and $\mathrm{NO}$ were emitted from the soil and $\mathrm{NO}_{2}$ was deposited into the soil, however, the fluxes were very small. Annual cumulative soil $\mathrm{N}_{2} \mathrm{O}$ emission averaged to $0.2 \mathrm{~kg} \mathrm{Nha}^{-1} \mathrm{yr}^{-1}$. Measuring $\mathrm{NO}$ emission and $\mathrm{NO}_{2}$ deposition from/to the soil was challenging because of the small fluxes. During the campaign in the autumn period 2011, measured NO-N emission was around $0.01 \mathrm{~kg} \mathrm{Nha}^{-1} \mathrm{yr}^{-1}$ and $\mathrm{NO}_{2}-\mathrm{N}$ deposition was even smaller.

\subsection{Nitrogen balance}

The inputs to the system were one order of magnitude higher than the outputs (Fig. 2). The total $\mathrm{N}$ accumulation was $7 \mathrm{~kg} \mathrm{Nha}^{-1} \mathrm{yr}^{-1}$. Dry deposition was higher than wet deposition, but they both were on the same order of magnitude. Approximately three fourths of the $\mathrm{N}$ lost from the system was in the form of gaseous $\mathrm{N}_{2} \mathrm{O}-\mathrm{N}$ emissions, and one third as $\mathrm{N}_{\text {org }}$ in the drainage flow. Nitrous oxide $\left(\mathrm{N}_{2} \mathrm{O}\right)$ emission to $\mathrm{N}$ deposition ratio was approximately 0.03 and $\mathrm{N}_{2} \mathrm{O}: \mathrm{NO}$ emission ratio was approximately 20 .

\subsection{Internal nitrogen cycling}

\subsubsection{Litter fall}

From 2006 to 2010, the amount of $\mathrm{N}$ flux in annual aboveground litter fall from trees varied from 14 to $22 \mathrm{~kg} \mathrm{Nha}^{-1} \mathrm{yr}^{-1}$, being on average $18 \mathrm{~kg} \mathrm{Nha}^{-1} \mathrm{yr}^{-1}$. Half of the $\mathrm{N}$ flux in the aboveground litter fall was in needles and leaves, 8.0 and $1.0 \mathrm{~kg} \mathrm{Nha}^{-1} \mathrm{yr}^{-1}$, respectively. Branches contributed about one fourth of the $\mathrm{N}$ in aboveground litter fall, $5.3 \mathrm{~kg} \mathrm{Nha}^{-1} \mathrm{yr}^{-1}$. Nitrogen flux in the litter fall of bark, reproductive matter and unidentified matter were 1.1, 0.35 and $2.1 \mathrm{~kg} \mathrm{Nha}^{-1} \mathrm{yr}^{-1}$, respectively.

\subsubsection{Senescence and retranslocation}

Nitrogen retranslocation from needles and leaves was estimated to be $21 \mathrm{~kg} \mathrm{Nha}^{-1} \mathrm{yr}^{-1}$ and $2.8 \mathrm{~kg} \mathrm{Nha}^{-1} \mathrm{yr}^{-1}$, respectively. This was $73 \%$ of the initial amount of $\mathrm{N}$ in the 

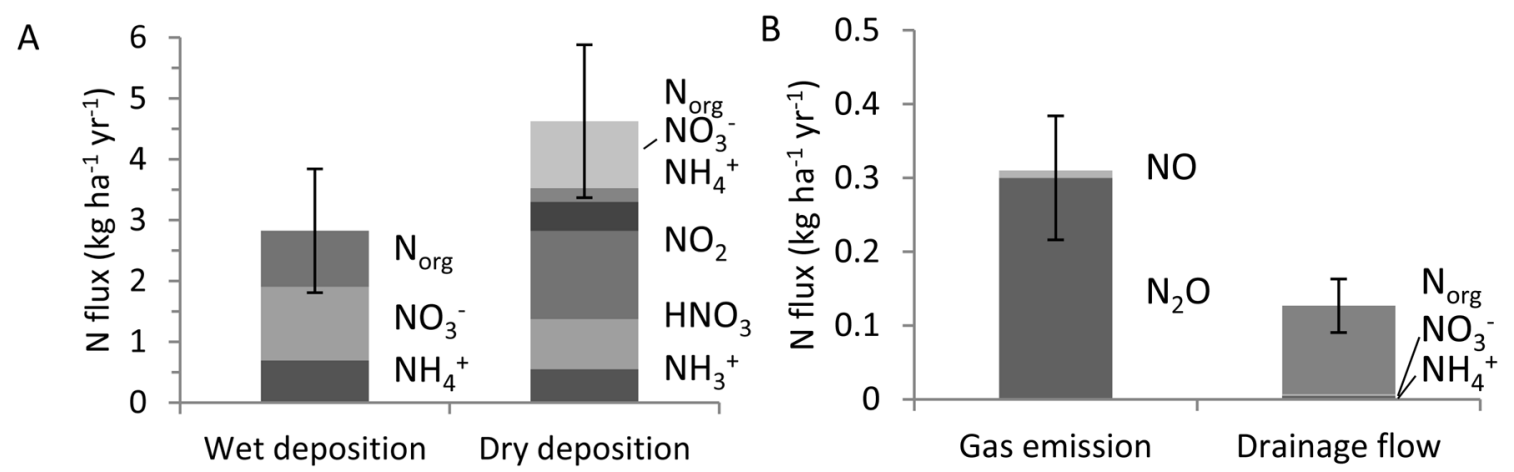

Fig. 2. Inputs (A) and outputs (B) of $\mathrm{N}$ in boreal Scots pine forest in Hyytiälä. Note the different y-scale in the images. The error bar of the wet deposition is based standard error of mean of the annual precipitation amount and on the uncertainty of estimating $\mathrm{N}$ concentration in precipitation from bulk deposition measurement. The error bar of the dry deposition represents the standard deviation between the four models used in Flechard et al. (2011) and the uncertainty of estimating $\mathrm{N}_{\text {org }}$. Systematic uncertainty in the models and uncertainty in the model input parameters are not included. The error bar of the gas emission is the standard error of mean of average flux between the chambers. The error bar of the drainage flow is the standard error of mean annual drainage flow of years 2006-2010.

foliage. Nitrogen retranslocation was higher than the $\mathrm{N}$ flux in the aboveground litter fall.

Nitrogen flux in litter fall of branches, bark, cones and unidentified litter was assumed to present the $\mathrm{N}$ loss in senescence. The senescence of needles and leaves was estimated to be 33 and $3.9 \mathrm{~kg} \mathrm{Nha}^{-1} \mathrm{yr}^{-1}$, respectively. The total senescence was $43 \mathrm{~kg} \mathrm{Nha}^{-1} \mathrm{yr}^{-1}$, which is approximately one fifth of the aboveground biomass $\mathrm{N}$ pool $\left(210 \mathrm{~kg} \mathrm{Nha}^{-1}\right)$.

\subsubsection{N use by plants}

Estimated $\mathrm{N}$ use for growth was $50 \mathrm{~kg} \mathrm{Nha}^{-1} \mathrm{yr}^{-1}$ (Fig. 3). Nitrogen uptake and retranslocation were as important sources for the $\mathrm{N}$ use, 26 and $24 \mathrm{~kg} \mathrm{~N} \mathrm{ha}^{-1} \mathrm{yr}^{-1}$, respectively. Nitrogen uptake comprised 19 and $7 \mathrm{~kg} \mathrm{Nha}^{-1} \mathrm{yr}^{-1}$ of net $\mathrm{N}$ release from decomposition and deposition, respectively.

Most of the used $\mathrm{N}, 36 \mathrm{~kg} \mathrm{Nha}^{-1} \mathrm{yr}^{-1}$, was allocated to the foliage. The amount of $\mathrm{N}$ used to grow branches, wood and bark were 7.8, 2.3 and $1.9 \mathrm{~kg} \mathrm{Nha}^{-1} \mathrm{yr}^{-1}$, respectively. The amount of $\mathrm{N}$ used to grow cones, seeds and flowers was relatively low, $0.35 \mathrm{~kg} \mathrm{Nha}^{-1} \mathrm{yr}^{-1}$. A relatively large amount, $2.1 \mathrm{~kg} \mathrm{ha}^{-1} \mathrm{yr}^{-1}$, of unidentified litter fall was measured. An equivalent amount was interpreted to be used by trees to grow an unknown biomass fraction.

\section{Discussion}

\subsection{Nitrogen balance and internal nitrogen cycling}

Overall $\mathrm{N}$ cycling at Hyytiälä Scots pine forest is presented in Fig. 4. The outputs of $\mathrm{N}$ from the system are very small, and $\mathrm{N}$ is accumulating to the system at a rate of $7 \mathrm{~kg} \mathrm{Nha}^{-1} \mathrm{yr}^{-1}$. Internal cycling of $\mathrm{N}$ within the forest is a very important source of $\mathrm{N}$ for the plants in this $\mathrm{N}$ limited ecosystem. Nitrogen retranslocation and $\mathrm{N}$ uptake are equally important $\mathrm{N}$ sources. Most of the assimilated $\mathrm{N}$ originates from the decomposition of organic matter. The atmospheric $\mathrm{N}$ deposition was about one third of the total $\mathrm{N}$ uptake. This means that release during decomposition is the main origin of $\mathrm{N}$ for the plant uptake, but also that $\mathrm{N}$ deposition has clearly increased the total $\mathrm{N}$ uptake, boosting the plant growth and productivity. Internal cycling and pools of $\mathrm{N}$ at Hyytiälä were systematically slightly higher than those of a similar 35-yr-old Scots pine forest in Mekrijärvi, southeast Finland (Helmisaari, 1995). Overall, the results of these studies agree very well.

The amount of $\mathrm{N}$ released from decomposition annually is approximately the same as the amount of $\mathrm{N}$ released to the soil in litter fall. We hypothesize that a considerable part of the $\mathrm{N}$ released in decomposition originates from fresh litter, which naturally contains more easily decomposable fractions than old litter does. Therefore, we conclude that the $\mathrm{N}$ release in the decomposition is at least partly dependent on the amount of litter fall. As the atmospheric $\mathrm{N}$ deposition increases the plant growth, and thus also the litter fall, we argue further that this effect accumulates over time. Therefore, based on the $\mathrm{N}$ balance, the $\mathrm{N}$ deposition increases plant productivity in three ways: (1) it directly increases the availability of plant-available $\mathrm{N},(2)$ it indirectly increases the availability of $\mathrm{N}$ by increasing the rate of retranslocation and the release of $\mathrm{N}$ from the decomposition, and (3) the indirect effect accumulates over time. In addition, it has long been known that $\mathrm{N}$ availability affects the leaf-to-fineroot ratio (Helmisaari et al., 2007; Ericsson, 1995), as hypothesized in the functional balance concept (Brouwer, 1962; Davidson, 1969). A low leaf-to-fine-root ratio reduces plant growth, because of the fact that when more carbon is allocated to the root system, less carbon is available for the foliage growth. The large maintenance costs of a large root system can be reduced by higher $\mathrm{N}$ availability, and successively 


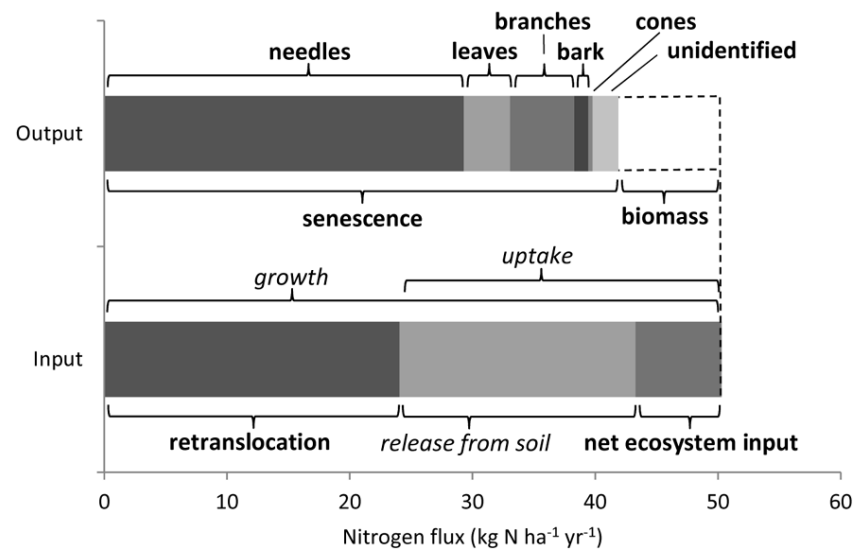

Fig. 3. Nitrogen balance of aboveground part of the trees in boreal Scots pine forest in Hyytiälä. Release from the soil is the minimum amount of $\mathrm{N}$ released from soil by decomposition. It is calculated based on the hypothesis that all the $\mathrm{N}$ from the atmospheric deposition was taken up by plants. The variables marked in bold are direct measurements and the variables marked in italics are calculated from the other variables as follows: Growth $=$ Senescence + Biomass increment; Uptake $=$ Growth Retranslocation; Release from soil = Uptake - Net ecosystem input; Net ecosystem input $=$ Deposition - Gaseous emissions - Drainage flow.

large growth enhancements can be achieved by increasing $\mathrm{N}$ input (Saarsalmi and Mälkönen, 2001; Hyvönen et al., 2008).

Over two thirds of the $\mathrm{N}$ available was used to grow new foliage. The residence time of foliage was $2.6 \mathrm{yr}$ and thus most of the allocated $\mathrm{N}$ was cycling quickly. Nitrogen allocated to structural biomass (wood, branches, bark) cycled much more slowly, the residence times (pool size/annual senescence) being 12 and $21 \mathrm{yr}$ for branches and bark, respectively. The $\mathrm{N}$ allocated to wood was immobilized for up to half of a millennium.

\subsection{Nitrogen pools}

We estimate that the soil N pool at Hyytiälä Scots pine forest is staying rather constant. Berg and Dise (2004) estimated that $\mathrm{N}$ has been accumulating in north-Scandinavian forest soils at a rate between 3.0 to $3.5 \mathrm{~kg} \mathrm{Nha}^{-1} \mathrm{yr}^{-1}$. This estimate is not different from our result, taking into account the uncertainty. It is worth noting that their estimation mostly considers preindustrial time and full succession of forests, whereas our study considers a young growing forest with higher $\mathrm{N}$ deposition rate.

Our estimations of biomass pools only consider the aboveground tree biomass. Based on the regression functions in Repola (2009), the coarse root $(>1 \mathrm{~cm})$ biomass was $14100 \mathrm{~kg}$ dry mass $(\mathrm{DM}) \mathrm{ha}^{-1}$. A fine root biomass including fine roots of the ground vegetation was $4760 \mathrm{~kg} \mathrm{DM} \mathrm{ha}^{-1}$ as reported for the study site in Ilvesniemi et al. (2009). Mälkönen (1974) reported coarse and fine root N contents

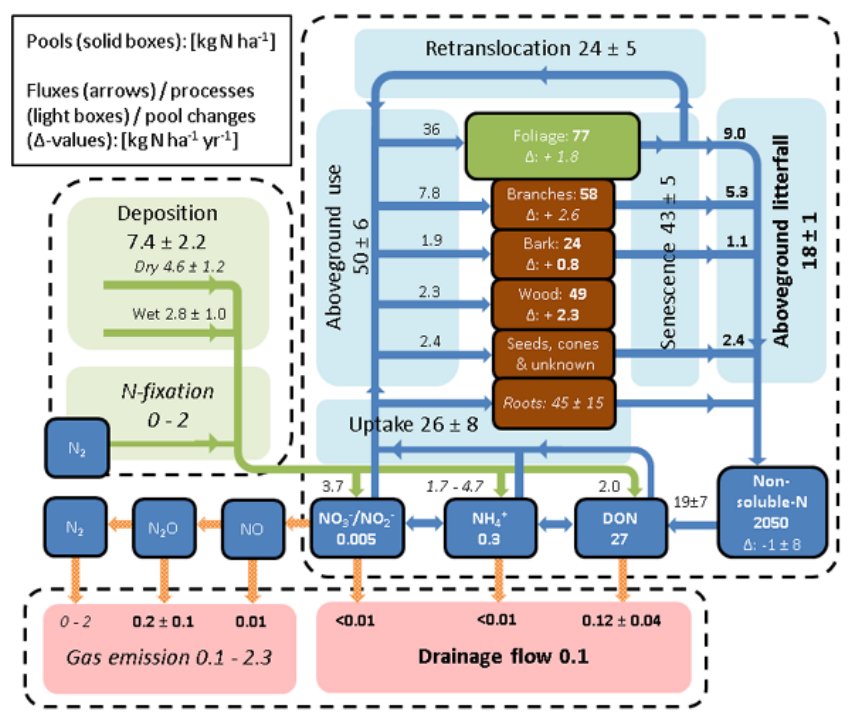

Fig. 4. Flow chart of nitrogen cycling in Hyytiälä Scots pine forest. The solid boxes are pools and the light boxes and arrows are processes. The $\Delta \mathrm{s}$ inside the boxes denote the annual pool change. Inputs, outputs and internal cycling of nitrogen are separated by dashed lines, and arrows are colored accordingly. The values originating from direct measurements are in bold. The values which are based on literature, or which are otherwise uncertain, are in italics. Systematic errors are mostly not taken into account in the uncertainty estimations.

of $0.92 \mathrm{mg} \mathrm{g}^{-1}$ and $4.79 \mathrm{mg} \mathrm{g}^{-1}$, respectively, for a $47-\mathrm{yr}-$ old Scots pine stand near the SMEAR II station, whereas Helmisaari et al. (2007) reported a Scots pine fine root $\mathrm{N}$ concentration of $7.7 \mathrm{mg} \mathrm{g}^{-1}$. Using these values, we got that the $\mathrm{N}$ pool in coarse roots was $13 \mathrm{~kg} \mathrm{~N} \mathrm{ha}^{-1}$ and in the fine root pool varied from 24 to $37 \mathrm{~kg} \mathrm{~N} \mathrm{ha}^{-1}$. Kulmala et al. (2008) reported that the total aboveground forest floor biomass at the study site was $1240 \mathrm{~kg} \mathrm{ha}^{-1}$. Using the plant species distribution reported by Kulmala et al. (2008) and the corresponding N concentrations presented by Mälkönen (1974), we get an estimate of $14 \mathrm{~kg} \mathrm{Nha}^{-1}$ in the aboveground forest floor at the SMEAR II station. As follows, the total biomass $\mathrm{N}$ in the ecosystem was approximately $265 \mathrm{~kg} \mathrm{~N} \mathrm{ha}^{-1}$. Roots and aboveground ground vegetation contributed about $16 \%$ and $5 \%$ of the total biomass $\mathrm{N}$ pool, respectively.

Based on the biomass equations presented by Repola $(2009,2008)$, we estimated that the foliage and coarse root $\mathrm{N}$ pool was increasing. The forest was partly thinned in early 2002 (Vesala et al., 2005). We did not observe any trend in the needle litter fall in the time series from 2003 to 2012, which would support the foliage $\mathrm{N}$ pool growth, although there was an increasing trend in the leaf litter fall. However, before the thinning, from 1998 to 2001, the needle litter fall was $36 \%$ ( $\pm 11 \%$; standard error) higher than that after the thinning. Therefore, we assume that the foliage and branch mass are probably still recovering from the thinning, and 
thus increasing. The increase in coarse root biomass given by biomass equations was $0.7 \mathrm{~kg} \mathrm{Nha}^{-1} \mathrm{yr}^{-1}$, but it is very difficult to estimate the validity of this value.

\subsection{Inputs and outputs}

The total losses of $\mathrm{N}$ from our study site in the form of $\mathrm{N}$ leaching or $\mathrm{N}$-oxide emissions were approximately $5 \%$ of the $\mathrm{N}$ inputs, which is much smaller proportion than those measured in Central European forest ecosystems with high $\mathrm{N}$ deposition (e.g. Kreutzer et al., 2009). Kreutzer et al. (2009) showed that in an N-saturated spruce forest (Höglwald) in Southern Germany, over $80 \%$ of the $\mathrm{N}$ deposition was lost in the form of $\mathrm{NO}_{3}^{-}$leaching and $\mathrm{N}_{2} \mathrm{O}$ and $\mathrm{NO}$ emissions.

At Hyytiälä, most of the $\mathrm{N}$ leaching was in the form of organic nitrogen $\left(\mathrm{N}_{\mathrm{org}}\right)$. This is in line with results of Mustajärvi et al. (2008), who found that DON ( $\mathrm{N}_{\text {org }}$ in our study) was the dominant $\mathrm{N}$ species in the percolation water of 16 pine and spruce forests in Finland. Mustajärvi et al. (2008) also found that the runoff of DON was larger than the input of DON into the forest canopy via atmospheric deposition. We found that the input of $\mathrm{N}_{\text {org }}$ into the forest was higher than the output in the runoff, which may be due to the fact that the measurement sites and the methods were different. Overall, our findings show that $\mathrm{N}_{\text {org }}$ is an important component of the $\mathrm{N}$ cycling in boreal forests.

$\mathrm{N}_{2}$ fixation and $\mathrm{N}_{2}$ emissions are two unknowns in the $\mathrm{N}$ balance of the Hyytiälä forest site. Symbiotic $\mathrm{N}_{2}$ fixing bacteria in the root system of alder and birch trees (Rönkkö et al., 1993; Smolander, 1990), and in association with common feather mosses (DeLuca et al., 2002, 2008; Zackrisson et al., 2004), have a potential to bring significant amounts of $\mathrm{N}$ into the boreal forest floor. However, due to the small coverage of alder and birch trees at our measurement site, we estimate that their role in bringing $\mathrm{N}$ into the forest is minimal. Also, based on our laboratory measurements of $\mathrm{N}_{2}$ fixation by forest floor mosses at the SMEAR II stand (unpublished data), we estimate that moss-related $\mathrm{N}_{2}$ fixation at Hyytiälä Scots pine forest is at the lower range of that $(0.1$ to $4 \mathrm{~kg} \mathrm{Nha}^{-1} \mathrm{yr}^{-1}$ ) reported for boreal forests by DeLuca et al. (2008, 2002) and Zackrisson et al. (2009). Personal communication with Maija Salemaa (Finnish Forest Research Institute) also supports the findings that $\mathrm{N}$ fixation by forest floor mosses in southern Finland is much smaller than that of the forest floor mosses in northern Finland.

Measuring $\mathrm{N}_{2}$ emission in the field is currently not possible, as the exchange of $\mathrm{N}_{2}$ cannot be resolved from the high background concentration of $\mathrm{N}_{2}$ in the air. There is no field measurement data available on $\mathrm{N}_{2}$ emissions of boreal ecosystems, whereas laboratory measurements indicate high $\mathrm{N}_{2}$ emissions (10-120 $\mathrm{kg} \mathrm{N} \mathrm{ha}^{-1} \mathrm{yr}^{-1}$ ) from temperate forest soils (Dannenmann et al., 2008; Butterbach-Bahl et al., 2002). Based on these results, we can expect that $N_{2}$ is also emitted from the soil at our measurement site; however, the rates remain unresolved. If the rates of $\mathrm{N}_{2}$ emissions are sig- nificant, they may reduce the estimated $\mathrm{N}$ accumulation rates in the forest, which underlines the importance of quantifying these $\mathrm{N}$ exchange rates. Using a $\mathrm{N}_{2} \mathrm{O}: \mathrm{N}_{2}$ emission ratio of 0.15 for $\mathrm{N}$ saturated Norway spruce forest (Butterbach-Bahl et al., 2002), we estimate that the $\mathrm{N}_{2}$ emission is on the order of $1 \mathrm{~kg} \mathrm{Nha}^{-1} \mathrm{yr}^{-1}$.

\section{Conclusions}

The main inputs, outputs, internal cycling and pools of $\mathrm{N}$ in a Scots pine forest at the SMEAR II station were quantified. Our measurements show that $\mathrm{N}$ is accumulating in this Scots pine forest at a rate of $7 \mathrm{~kg} \mathrm{~N} \mathrm{ha}^{-1} \mathrm{yr}^{-1}$. Most of the $\mathrm{N}$ accumulates to the aboveground biomass, whereas the soil $\mathrm{N}$ pool is close to a steady state. The largest external $\mathrm{N}$ input into the forest was atmospheric deposition. Outputs from the system were very small and emissions to the atmosphere in the form of $\mathrm{N}_{2} \mathrm{O}$ and $\mathrm{NO}$ were higher than the $\mathrm{N}$ flow in drainage in the form of $\mathrm{N}_{\text {org }}, \mathrm{NH}_{4}^{+}$or $\mathrm{NO}_{3}^{-}$. High uncertainties remain in the quantification of the input via $\mathrm{N}_{2}$ fixation and especially in the output via $\mathrm{N}_{2}$ emissions from the soil.

Boreal forests are considered to be $\mathrm{N}$ limited; though these ecosystems are not deprived of $\mathrm{N}$, the large organic $\mathrm{N}$ pool in the soil is not directly available for plant uptake. We estimated that the release of $\mathrm{N}$ from litter decomposition and retranslocation are the main sources of $\mathrm{N}$ for the plants. Annually, the plant uptake rate of $\mathrm{N}$ originating from the decomposition is at least $18 \mathrm{~kg} \mathrm{Nha}^{-1} \mathrm{yr}^{-1}$. The fraction of assimilated $\mathrm{N}$ originating directly from the atmospheric deposition was up to $30 \%$. The main source of $\mathrm{N}$ for plant use is internal cycling, demonstrated by that half of the $\mathrm{N}$ used for growth originated from retranslocation.

Organic $\mathrm{N}$ deposition in the studied forest was an important component of the $\mathrm{N}$ balance, and $\mathrm{N}$ losses in drainage flow were mostly in the form of organic $\mathrm{N}$. The largest output of $\mathrm{N}$ from the system was $\mathrm{N}_{2} \mathrm{O}$ emission, while $\mathrm{NO}$ emission was extremely small.

Acknowledgements. This study was supported by the Maj and Tor Nessling Foundation, the Academy of Finland Center of Excellence program (project no. 1118615), the post-doctoral project 1127756, and the Academy Fellow project 130984. This study is part of Nitroeurope-IP, ICOS-EU, ICOS-SA, InGOS, GHG Europe, and DEFROST projects. We gratefully thank the staff of SMEAR II for continuous efforts in providing data, the referees Klaus Butterbach-Bahl and Kim Pilegaard for their valuable comments and Rae Ellen Bichell for the help with improving the language.

Edited by: U. Skiba 


\section{References}

Aber, J., McDowell, W., Nadelhoffer, K., Magill, A., Berntson, G., Kamakea, M., McNulty, S., Currie, W., Rustad, L., and Fernandez, I.: Nitrogen saturation in temperate forest ecosystems - Hypotheses revisited, Bioscience, 48, 921-934, 1998.

Berg, B. and Dise, N.: Calculating the long-term stable nitrogen sink in northern European forests, Acta. Oecol., 26, 15-21, doi:10.1016/j.actao.2004.03.003, 2004.

Berg, B. and McClaugherty, C.: Plant litter: decomposition, humus formation, carbon sequestration, Springer-Verlag, Berlin, 2003.

Braekke, F. H., Salih, N., and Ingerslev, M.: 5.6. Nutrient status of stands-needle analysis, in: Nutrition and growth of Norway spruce forests in a Nordic climatic and deposition gradient 1998, edited by: Andersson, F., Braekke, F. H., and Hallbäcken, L., Nordic Council of Minisers, Copenhagen, Denmark, 41 pp., 1998.

Brouwer, R.: Nutritive influences on the distribution of dry matter in the plant, Neth. J. Agr. Sci., 10, 399-408, 1962.

Butterbach-Bahl, K., Gasche, R., Willibald, G., and Papen, H.: Exchange of N-gases at the Hoglwald Forest - A summary, Plant Soil, 240, 117-123, 2002.

Dannenmann, M., Butterbach-Bahl, K., Gasche, R., Willibald, G., and Papen, H.: Dinitrogen emissions and the $\mathrm{N}_{2}: \mathrm{N}_{2} \mathrm{O}$ emission ratio of a Rendzic Leptosol as influenced by $\mathrm{pH}$ and forest thinning, Soil Biol. Biochem., 40, 2317-2323, doi:10.1016/j.soilbio.2008.05.009, 2008.

Davidson, R. L.: Effect of Root/Leaf Temperature Differentials on Root/Shoot Ratios in Some Pasture Grasses and Clover, Ann. Bot.-London, 33, 571-577, 1969.

DeLuca, T. H., Zackrisson, O., Nilsson, M. C., and Sellstedt, A.: Quantifying nitrogen-fixation in feather moss carpets of boreal forests, Nature, 419, 917-920, doi:10.1038/Nature01051, 2002.

DeLuca, T. H., Zackrisson, O., Gundale, M. J., and Nilsson, M. C.: Ecosystem feedbacks and nitrogen fixation in boreal forests, Science, 320, 1181-1181, doi:10.1126/science.1154836, 2008.

Dorich, R. A. and Nelson, D. W.: Evaluation of Manual Cadmium Reduction Methods for Determination of Nitrate in Kcl Extracts of Soils, Soil Sci. Soc. Am. J., 48, 72-75, 1984.

Drebs, A., Nordlund, A., Karlsson, P., Helminen, J., and Rissanen, P.: Tilastoja suomen ilmastosta 1971-2000 (Climatological statistics of Finland 1971-2000), Finnish Meteorological Institute, Helsinki, Finland, 2002.

Ericsson, T.: Growth and shoot: root ratio of seedlings in relation to nutrient availability, Plant Soil, 168-169, 205-214, doi:10.1007/bf00029330, 1995.

FAO-UNESCO-ISRIC: Revised Legend, Soil Map of the World, World soil resources rep., FAO, Rome, Italy, 60 pp., 1988.

Fischer, R., Lorenz, M., Köhl, M., Mues, V., Granke, O., Iost, S., van Dobben, H., Reinds, G. J., and de Vries, W.: The Condition of Forests in Europe, 2010 Executive Report., ICP Forests and European Commission, Hamburg and Brussels, Germany, Belgium, 22 pp., 2010.

Flechard, C. R., Nemitz, E., Smith, R. I., Fowler, D., Vermeulen, A. T., Bleeker, A., Erisman, J. W., Simpson, D., Zhang, L., Tang, Y. S., and Sutton, M. A.: Dry deposition of reactive nitrogen to European ecosystems: a comparison of inferential models across the NitroEurope network, Atmos. Chem. Phys., 11, 2703-2728, doi:10.5194/acp-11-2703-2011, 2011.
Galloway, J. N., Aber, J. D., Erisman, J. W., Seitzinger, S. P., Howarth, R. W., Cowling, E. B., and Cosby, B. J.: The nitrogen cascade, Bioscience, 53, 341-356, 2003.

Gruber, N. and Galloway, J. N.: An Earth-system perspective of the global nitrogen cycle, Nature, 451, 293-296, 2008.

Hari, P. and Kulmala, M.: Station for measuring ecosystematmosphere relations (SMEAR II), Boreal. Environ. Res., 10, 315-322, 2005.

Hattenschwiler, S. and Vitousek, P. M.: The role of polyphenols in terrestrial ecosystem nutrient cycling, Trends. Ecol. Evol., 15, 238-243, 2000.

Helmisaari, H. S.: Nutrient Retranslocation within the Foliage of Pinus-Sylvestris, Tree Physiol., 10, 45-58, 1992.

Helmisaari, H. S.: Nutrient Cycling in Pinus-Sylvestris Stands in Eastern Finland, Plant Soil, 168, 327-336, 1995.

Helmisaari, H. S., Derome, J., Nojd, P., and Kukkola, M.: Fine root biomass in relation to site and stand characteristics in Norway spruce and Scots pine stands, Tree Physiol., 27, 1493-1504, 2007.

Holland, E. A., Braswell, B. H., Sulzman, J., and Lamarque, J. F.: Nitrogen deposition onto the United States and western Europe: Synthesis of observations and models, Ecol. Appl., 15, 38-57, 2005.

Hyvönen, R., Persson, T., Andersson, S., Olsson, B., Agren, G. I., and Linder, S.: Impact of long-term nitrogen addition on carbon stocks in trees and soils in northern Europe, Biogeochemistry, 89, 121-137, doi:10.1007/s10533-007-9121-3, 2008.

Ilvesniemi, H., Levula, J., Ojansuu, R., Kolari, P., Kulmala, L., Pumpanen, J., Launiainen, S., Vesala, T., and Nikinmaa, E.: Long-term measurements of the carbon balance of a boreal Scots pine dominated forest ecosystem, Boreal. Environ. Res., 14, 731753, 2009.

Ilvesniemi, H., Pumpanen, J., Duursma, R., Hari, P., Keronen, P., Kolari, P., Kulmala, M., Mammarella, I., Nikinmaa, E., Rannie, U., Pohja, T., Siivola, E., and Vesala, T.: Water balance of a boreal Scots pine forest, Boreal. Environ. Res., 15, 375-396, 2010.

Jones, D. L. and Kielland, K.: Soil amino acid turnover dominates the nitrogen flux in permafrost-dominated taiga forest soils, Soil Biol. Biochem., 34, 209-219, 2002.

Kielland, K., McFarland, J., and Olson, K.: Amino acid uptake in deciduous and coniferous taiga ecosystems, Plant Soil, 288, 297307, doi:10.1007/s11104-006-9117-0, 2006.

Kielland, K., McFarland, J. W., Ruess, R. W., and Olson, K.: Rapid cycling of organic nitrogen in taiga forest ecosystems, Ecosystems, 10, 360-368, doi:10.1007/s10021-007-9037-8, 2007.

Kolari, P., Bäck, J., Taipale, R., Ruuskanen, T. M., Kajos, M. K., Rinne, J., Kulmala, M., and Hari, P.: Evaluation of accuracy in measurements of VOC emissions with dynamic chamber system, Atmos. Environ., 62, 344-351, doi:10.1016/j.atmosenv.2012.08.054, 2012.

Korhonen, J. F. J., Pumpanen, J., and Pihlatie, M.: Total nitrogen deposition to a boreal forest - organic dry nitrogen deposition estimated, in: Proceedings of Finnish Center of Excellence in "Physics, Chemistry, Biology and Meteorology of Atmospheric Composition and Climate Change", and Nordic Center of Excellence in "Cryosphere-Atmosphere Interactions in a Changing Arctic Climate" Annual Meetings 2012, edited by: Kulmala, M., Lappalainen, H. K., Boy, M., Brus, M., and Nieminen, T., Report Series in Aerosol Science, 134, 375-379, 2012. 
Kreutzer, K., Butterbach-Bahl, K., Rennenberg, H., and Papen, $\mathrm{H}$.: The complete nitrogen cycle of an $\mathrm{N}$-saturated spruce forest ecosystem, Plant Biology, 11, 643-649, doi:10.1111/j.14388677.2009.00236.x, 2009.

Kubin, E.: Leaching of nitrate nitrogen into the groundwater after clear felling and site preparation, Boreal. Environ. Res., 3, 3-8, 1998.

Kulmala, L., Launiainen, S., Pumpanen, J., Lankreijer, H., Lindroth, A., Hari, P., and Vesala, T.: $\mathrm{H}_{2} \mathrm{O}$ and $\mathrm{CO}_{2}$ fluxes at the floor of a boreal pine forest, Tellus B, 60, 167-178, doi:10.1111/j.16000889.2007.00327.x, 2008.

Magnani, F., Mencuccini, M., Borghetti, M., Berbigier, P., Berninger, F., Delzon, S., Grelle, A., Hari, P., Jarvis, P. G., Kolari, P., Kowalski, A. S., Lankreijer, H., Law, B. E., Lindroth, A., Loustau, D., Manca, G., Moncrieff, J. B., Rayment, M., Tedeschi, V., Valentini, R., and Grace, J.: The human footprint in the carbon cycle of temperate and boreal forests, Nature, 447, 848-850, doi:10.1038/Nature05847, 2007.

Maljanen, M., Alm, J., Martikainen, P. J., and Repo, T.: Prolongation of soil frost resulting from reduced snow cover increases nitrous oxide emissions from boreal forest soil, Boreal. Environ. Res., 15, 34-42, 2010.

Mälkönen, E.: Annual Primary production and nutrient cycle in some Scots pine stands, Comm. Inst. For. Fen., Finnish Forest Research Institute, Finland, 87 pp., 1974.

Mustajärvi, K., Merila, P., Derome, J., Lindroos, A. J., Helmisaari, H. S., Nojd, P., and Ukonmaanaho, L.: Fluxes of dissolved organic and inorganic nitrogen in relation to stand characteristics and latitude in Scots pine and Norway spruce stands in Finland, Boreal. Environ. Res., 13, 3-21, 2008.

Neff, J. C., Holland, E. A., Dentener, F. J., McDowell, W. H., and Russell, K. M.: The origin, composition and rates of organic nitrogen deposition: A missing piece of the nitrogen cycle?, Biogeochemistry, 57, 99-136, 2002.

Palmroth, S. and Hari, P.: Evaluation of the importance of acclimation of needle structure, photosynthesis, and respiration to available photosynthetically active radiation in a Scots pine canopy, Can. J. Forest Res., 31, 1235-1243, 2001.

Pihlatie, M., Pumpanen, J., Rinne, J., Ilvesniemi, H., Simojoki, A., Hari, P., and Vesala, T.: Gas concentration driven fluxes of nitrous oxide and carbon dioxide in boreal forest soil, Tellus B, 59, 458469, doi:10.1111/j.1600-0889.2007.00278.x, 2007.

Pilegaard, K., Skiba, U., Ambus, P., Beier, C., Brüggemann, N., Butterbach-Bahl, K., Dick, J., Dorsey, J., Duyzer, J., Gallagher, M., Gasche, R., Horvath, L., Kitzler, B., Leip, A., Pihlatie, M. K., Rosenkranz, P., Seufert, G., Vesala, T., Westrate, H., and Zechmeister-Boltenstern, S.: Factors controlling regional differences in forest soil emission of nitrogen oxides ( $\mathrm{NO}$ and $\mathrm{N}_{2} \mathrm{O}$ ), Biogeosciences, 3, 651-661, doi:10.5194/bg-3-651-2006, 2006.
Pinho, P., Theobald, M. R., Dias, T., Tang, Y. S., Cruz, C., MartinsLoucao, M. A., Maguas, C., Sutton, M., and Branquinho, C.: Critical loads of nitrogen deposition and critical levels of atmospheric ammonia for semi-natural Mediterranean evergreen woodlands, Biogeosciences, 9, 1205-1215, doi:10.5194/bg-91205-2012, 2012.

Raivonen, M., Keronen, P., Vesala, T., Kulmala, M., and Hari, P.: Measuring shoot-level NOx flux in field conditions: the role of blank chambers, Boreal. Environ. Res., 8, 445-455, 2003.

Repola, J.: Biomass Equations for Birch in Finland, Silva Fenn, 42, 605-624, 2008.

Repola, J.: Biomass Equations for Scots Pine and Norway Spruce in Finland, Silva Fenn., 43, 625-647, 2009.

Rönkkö, R., Smolander, A., Nurmiaholassila, E. L., and Haahtela, K.: Frankia in the Rhizosphere of Nonhost Plants - a Comparison with Root-Associated N2-Fixing Enterobacter, Klebsiella and Pseudomonas, Plant Soil, 153, 85-95, 1993.

Saarsalmi, A. and Mälkönen, E.: Forest fertilization research in Finland: A literature review, Scand. J. Forest Res., 16, 514-535, 2001.

Smolander, A.: Frankia Populations in Soils under Different Tree Species - with Special Emphasis on Soils under Betula-Pendula, Plant Soil, 121, 1-10, 1990.

Syri, S., Fronzek, S., Karvosenoja, N., and Forsius, M.: Sulphur and nitrogen oxides emissions in Europe and deposition in Finland during the 21st century, Boreal. Environ. Res., 9, 185-198, 2004.

Vesala, T., Suni, T., Rannik, U., Keronen, P., Markkanen, T., Sevanto, S., Gronholm, T., Smolander, S., Kulmala, M., Ilvesniemi, H., Ojansuu, R., Uotila, A., Levula, J., Makela, A., Pumpanen, J., Kolari, P., Kulmala, L., Altimir, N., Berninger, F., Nikinmaa, E., and Hari, P.: Effect of thinning on surface fluxes in a boreal forest, Global Biogeochem. Cy., 19, GB2001, doi:10.1029/2004gb002316, 2005.

Westman, C. J.: A simple device for sampling of volumetric forest soil cores, Silva Fenn., 29, 247-251, 1995.

Zackrisson, O., DeLuca, T. H., Nilsson, M. C., Sellstedt, A., and Berglund, L. M.: Nitrogen fixation increases with successional age in boreal forests, Ecology, 85, 3327-3334, 2004.

Zackrisson, O., DeLuca, T. H., Gentili, F., Sellstedt, A., and Jaderlund, A.: Nitrogen fixation in mixed Hylocomium splendens moss communities, Oecologia, 160, 309-319, doi:10.1007/s00442-009-1299-8, 2009. 